IRSH 53 (2008), Supplement, pp. I-3 doi:I0.I0I7/S002085900800357X

(C) 2008 Internationaal Instituut voor Sociale Geschiedenis

\title{
Preface: S.R. Epstein (1960-2007) and the Guilds
}

\author{
MAARTEN PRAK
}

The final comments in the conference that led to this volume were made by S.R. (Larry) Epstein. For a decade or so, he had been a commentator at many a conference, not least, perhaps, because that role fitted his argumentative style of scholarship. In this particular case, Epstein had been invited also because of his specific interest in guilds, which were to play a pivotal role in his major new project on technology in premodern Europe. Tragically, that project was never completed, because of his untimely death just a few months after the conference.

In the small but influential body of work relating to guilds which he published during his lifetime, Epstein made three interrelated claims. ${ }^{\mathrm{I}}$ First and foremost, he insisted that, contrary to the received wisdom among economists and economic historians, guilds had overall been beneficial to the premodern economies of Europe. Secondly, those beneficial effects were specifically related to the guilds' contribution to skills training. And thirdly, the economic environments created by guilds were oftentimes conducive to technological innovation.

By the time Epstein published his paper "Craft Guilds, Apprenticeship, and Technological Change in Premodern Europe" in The Journal of Economic History in 1998, the renewed interest in guilds had been underway for approximately two decades. ${ }^{2}$ Much of the literature that appeared during those two decades was an attempt to understand why institutions that allegedly had highly deleterious consequences for economic

${ }^{1}$ It includes S.R. Epstein, "Craft Guilds, Apprenticeship, and Technological Change in Premodern Europe", The Journal of Economic History, 58 (1998), pp. 684-713; idem et al. (eds), Guilds, Economy and Society (Madrid, I998); idem, "Labour Mobility, Journeyman Organisations and Markets in Skilled Labour Europe, I4th-I 8th centuries", in L. Hilaire-Perez and A. Garçon (eds), Pratiques historiques de l'innovation, historicité de l'économie des savoirs (I2e-Ige siècles) (Paris, 2004), and in M. Arnoux and P. Monnet (eds), Le technician dans la cité en Europe occidentale I250-I650 (Rome, 2004), pp. 25I-269; idem, "Apprenticeship", "Guilds", and "Journeymen", all in J. Mokyr (ed.), The Oxford Encyclopedia of Economic History, s vols (Oxford, 2003); idem, "Craft Guilds in the Pre-modern Economy: A Discussion”, Economic History Review, 6I (2008), pp. I55-174; idem and Maarten Prak (eds), Guilds, Innovation and the European Economy, I400-I800 (Cambridge, 2008).

${ }^{2}$ For the historiography and various specific aspects of guild history, see S.R. Epstein and Maarten Prak, "Introduction: Guilds, Innovation, and the European Economy, I400-I800", in idem, Guilds, Innovation and the European Economy, I400-I800, pp. I-24. 
development managed nonetheless to survive for the best part of a thousand years. Most guild historians had suggested that though guilds might have had disadvantages for the economy, their political, social, and cultural role made them nonetheless useful to contemporaries. It was also suggested that their economic harm was limited, because they were much more "flexible" than their critics had assumed on the basis of a study of guilds regulations.

Epstein took the debate squarely back to the economy by insisting that the guilds' critics, starting inevitably with Adam Smith, had got it wrong. Those critics had focused on the "monopolies" to which the regulations referred so often. In fact, those monopolies had been very difficult to enforce, and much of the evidence suggests that guild membership was much more open than had previously been thought. Instead of concentrating on how guilds controlled markets, or rather failed to control them, economic historians should, Epstein argued, consider the contributions guilds made to the formation of the skilled workforce.

Epstein's interest in skill formation was coupled with a growing interest on his part in the nature of technological knowledge. ${ }^{3}$ Manual skills were less easily acquired than intellectuals sometimes assumed, he argued, especially in the more advanced industries. Moreover, those skills could be acquired only through on-the-job training, through a learning-by-doing process, because of the tacit nature of those skills. In the absence of a state school system, the guilds provided the institutional framework for training the skilled workforce. Their main function was to help overcome the externalities of individual training arrangements, especially the potential for masters to exploit their apprentices, and vice versa.

Focusing on human capital formation allowed Epstein to question another cliché concerning the guilds, namely their technological conservatism. He argued that through their involvement in training, which in Germany and France could also include temporary migration by apprentices, guilds were actually an important force for technological innovation in the premodern period. Rather than the result of a deliberate search for novelty, innovation before the Industrial Revolution was primarily the unintended consequence of labour mobility, Epstein argued. Thanks to labour mobility, pools of knowledge from various European regions could interact, and this interaction led to the emergence of new products and new technologies.

These ideas were going to be the core of Epstein's next major book, provisionally entitled Secret Knowledge, Craftsmen, Engineers, and the Rise of the West. The first part would be devoted to "Generating and

3 See also S.R. Epstein, "Property Rights to Technological Knowledge in Premodern Europe, I 300-I800", The American Economic Review, 94 (2004), pp. 382-387. 
Transmitting Technological Knowledge", and had been planned to include two chapters on "guild-based training, teaching and innovation". ${ }^{4} \mathrm{He}$ had been collecting material for this book during a three-year research sabbatical, but the writing up would have to wait until after his stint as Head of the Economic History Department at the London School of Economics, which had begun in 2005. Such was the situation when Larry died, completely unexpectedly, in the early hours of 3 February 2007. After his death, a volume was published by Cambridge University Press, edited by Larry and the present author: Guilds, Innovation and the European Economy, I400-I800, which included not only a reprint of Larry's 1998 article but also a set of essays elaborating various aspects of his own, as well as other, new ideas on the economic impact of the guilds. That book, together with his other essays, will serve as a lasting reminder of his contribution to the economic history of the guilds. The editors of the present volume wish to honour Larry's memory by dedicating this volume to him. ${ }^{5}$

${ }^{4}$ I am quoting here from a table of contents found on his computer.

5 Another volume has also been dedicated to his memory: Bert De Munck, Steven L. Kaplan, and Hugo Soly (eds), Learning on the Shop Floor: Historical Perspectives on Apprenticeship (Oxford, 2007). 